\title{
Gordonia alkanivorans sp. nov., isolated from tar-contaminated soil
}

\author{
Christel Kummer, ${ }^{1}$ Peter Schumann ${ }^{2}$ and Erko Stackebrandt ${ }^{2}$
}

1 Hans-Knöll-Institut für Naturstoff-Forschung e.V., D-07745 Jena, Germany

2 DSMZ - Deutsche Sammlung von Mikroorganismen und Zellkulturen $\mathrm{GmbH}$, D-38124 Braunschweig, Germany

\author{
Author for correspondence: Christel Kummer. Tel: +4936416566 66. Fax: +493641656652. \\ e-mail: chkummer@pmail.hki-jena.de
}

\begin{abstract}
Twelve bacterial strains isolated from tar-contaminated soil were subjected to a polyphasic taxonomic study. The strains possessed meso-diaminopimelic acid as the diagnostic diamino acid of the peptidoglycan, $M K-9\left(H_{2}\right)$ as the predominant menaquinone, long-chain mycolic acids of the Gordonia-type, straight-chain saturated and monounsaturated fatty acids, and considerable amounts of tuberculostearic acid. The G+C content of the DNA was $68 \mathrm{~mol} \%$. Chemotaxonomic and physiological properties and 165 rDNA sequence comparison results indicated that these strains represent a new species of the genus Gordonia. Because of the ability of these strains to use alkanes as a carbon source, the name Gordonia alkanivorans is proposed. The type strain of Gordonia alkanivorans sp. nov. is strain HKI 0136' (=DSM 44369').
\end{abstract}

Keywords: Actinomycetales, Gordonia alkanivorans sp. nov., tar-contaminated soil, degradation, alkanes

\section{INTRODUCTION}

The genus Gordonia belongs to the family Gordoniaceae of the suborder Corynebacterineae within the order Actinomycetales (Stackebrandt et al., 1997). At present, this genus contains nine species: Gordonia aichiensis, Gordonia amarae, Gordonia bronchialis, Gordonia hirsuta, Gordonia hydrophobica, Gordonia rhizosphera, Gordonia rubropertincta, Gordonia sputi and Gordonia terrae. Members of the genus Gordonia were distinguished from rapidly growing mycobacteria mainly by the lack of acid-fastness and the absence of aryl sulfatase, and from the genus Nocardia on the basis of a positive nitrate reduction, the ability to form acid from mannose, the utilization of sucrose as sole carbon source (Tsukamura, 1971) and the absence of a mycelium [with the exception of $G$. amarae which shows weakly branched hyphae (Klatte et al., 1994)]. After the establishment of the genus Gordonia (Gordona) (Tsukamura, 1971), its status was controversial (Goodfellow \& Alderson, 1977) until the distinctness of this taxon from neighbouring taxa was confirmed by combining phylogenetic and chemotaxonomic results (Stackebrandt $e t$

Abbreviation: meso- $\mathrm{A}_{2} \mathrm{pm}$, meso-diaminopimelic acid.

The EMBL accession number for the 16S rDNA sequence of strain HKI $0136^{\top}$ is $\mathrm{Y} 18054$. $a l ., 1988)$. The genus was emended (Stackebrandt et al., 1988) to accommodate Rhodococcus species containing mycolic acids with 48-66 carbon atoms and MK-9( $\left.\mathbf{H}_{2}\right)$ as the predominant menaquinone. Rhodococcus aichiensis and Nocardia amarae were reclassified as Gordonia aichiensis and Gordonia amarae, respectively (Klatte et al., 1994; Ruimy et al., 1994). Further species have been added recently: $G$. hydrophobica (Bendinger et al., 1995), G. hirsuta (Klatte et al., 1996) and G. rhizosphera (Takeuchi \& Hatano, 1998).

Members of the genus Gordonia are widely distributed, as generally described for other mycolic acid-containing actinomycetes (Goodfellow, 1992; Klatte et al., 1996). Gordonia species were isolated from various soil samples of terrestrial and aquatic habitats, but also from biofilters for waste gas treatment (Bendinger et al., 1995; Klatte et al., 1996). Members of the genus Gordonia were cultivated from soil by prior treatment with alkali and from sputa of patients with lung cavities or bronchiectasis (Tsukamura, 1971, 1991; Tsukamura \& Yano, 1985; Riegel et al., 1994).

This study describes the taxonomic characterization of novel Gordonia strains by a polyphasic approach. Strains were isolated from tar- and phenol-contaminated soil of the former tar factory in Rositz (Eastern Thuringia, Germany) in the course of a screening program for $n$-alkane-degrading bacteria. These strains are characterized by their ability to degrade 
hexadecane and differ from known Gordonia species in their mycolic acid patterns.

\section{METHODS}

Bacterial strains and cultivation conditions. Bacterial type strains used were Corynebacterium glutamicum DSM $20300^{\mathrm{T}}$, Dietzia maris DSM 43672,$G$. aichiensis DSM 43978,$G$. amarae DSM 43392 ${ }^{\mathrm{T}}$, G. bronchialis DSM $43247^{\mathrm{T}}$ ( = NCTC $\left.10667^{\mathrm{T}}\right), G$. hirsuta DSM 44140 ${ }^{\mathrm{T}}$, G. hydrophobica DSM $44015^{\mathrm{T}}, G$. rubropertincta DSM $43197^{\mathrm{T}}, G$. sputi DSM $43896^{\mathrm{T}}$, G. terrae DSM $43249^{\mathrm{T}}$ (= ATCC 25594 ${ }^{\mathrm{T}}$ ), Nocardia carnea DSM $43397^{\mathrm{T}}$, Rhodococcus rhodochrous DSM $43241^{\mathrm{T}}$ and Tsukamurella paurometabola DSM $20162^{\mathrm{T}}$.

Twelve bacterial strains HKI 0134, HKI 0135, HKI $0136^{\mathrm{T}}$ $\left(=\mathrm{DSM} 44369^{\mathrm{T}}\right)$, HKI 0144, HKI 0145, HKI 0146, HKI 0147, HKI 0148, HKI 0149, HKI 0150, HKI 0151 and HKI 0152 were (among many others) isolated from a soil sample taken from the contaminated area of the former tar factory in Rositz (Germany) at a depth of about $10 \mathrm{~cm}$. The chemical characteristics of the soil sample were: $1.61 \mathrm{mg}$ light volatile aromatic hydrocarbons $\mathrm{kg}^{-1}$ such as benzene, toluene, ethylbenzene and xylenes; $18.6 \mathrm{~g}$ aliphatic hydrocarbons $\mathrm{kg}^{-1}$, oils $; 1.975 \mathrm{~g}$ polycyclic aromatic hydrocarbons $\mathrm{kg}^{-1}$ (a total of 16 compounds, e.g. pyrene, fluorene, chrysene, phenanthrene, benzopyrene, benzofluoranthrene, naphthalene); and $334 \mathrm{mg}$ phenol $\mathrm{kg}^{-1}$. These data were provided by the tar factory in Rositz. The soil sample was collected in late April 1996 and stored at $4{ }^{\circ} \mathrm{C}$ until isolation of the strains in October 1996.

The selective enrichment culture technique used n-hexane as sole carbon source. For preparation of the cultivation medium, $5 \mathrm{~g}$ contaminated soil was extracted with $20 \mathrm{ml} \mathrm{n}$ hexane. After extraction and filtration, $0.25 \mathrm{ml}$ hexane/soil extract (containing many aromatic and aliphatic hydrocarbons) was mixed with $8 \mathrm{ml}$ Brushnell-Haas-Bouillon (Difco) and the mixture was autoclaved. For the cultivation medium, $0.3 \mathrm{ml}$ each vitamin solution, described for the $\mathrm{HV}$ agar (Hayakawa \& Nonomura, 1987), $\mathrm{S}_{1}$ solution $(17 \% \mathrm{w} / \mathrm{v}$ $\mathrm{KCl} ; 0.5 \% \mathrm{MgSO}_{4} .7 \mathrm{H}_{2} \mathrm{O} ; 0.2 \% \mathrm{CaCO}_{3}$ in distilled water), $\mathrm{S}_{2}$ solution $\left(0 \cdot 1 \% \mathrm{FeSO}_{4} .7 \mathrm{H}_{2} \mathrm{O}\right.$ in distilled water $)$ and $1 \mathrm{ml}$ diluted soil $/ \mathrm{NaCl}$ suspension ( $1 \mathrm{~g}$ soil and $10 \mathrm{ml} 0.85 \%$ $\mathrm{NaCl}$, shaken for $1 \mathrm{~h}$ at $28{ }^{\circ} \mathrm{C}$, then diluted $1: 10$ ) were also added. After $5 \mathrm{~d}$ aerobic cultivation at $28^{\circ} \mathrm{C}$, the organisms were isolated by using the dilution plating technique on rich (R) medium (Yamada \& Komagata, 1972) agar plates. General laboratory cultivation was performed at $28^{\circ} \mathrm{C}$ on solidified or liquid R medium. For chemotaxonomic analysis, strains were cultivated for $24 \mathrm{~h}$ in liquid organic medium M 79 (Prauser et al., 1997) or in tryptic soy broth (TSB; Difco) at $28^{\circ} \mathrm{C}$.

Morphological and physiological characteristics. Colony morphology was observed with a stereo microscope Olympus SZ 11. Cell morphology was determined by phasecontrast microscopy (Olympus BH-2 microscope) using an ocular X10 and an objective X100/1-25. Ultrastructure was demonstrated by the freeze-fracture technique. An electron micrograph of the replica was made with an electron microscope EM 902 (Carl Zeiss) at a primary magnification of 5700 . The motility was studied by a hanging drop method. Cell dimensions were measured with a phase-contrast microscope (Olympus system microscope BX 50) with computing image analysis system VIS $5504 \mathrm{H}$ (Jentech). Gram-staining was performed according to Hucker's modi- fication (Cowan \& Steel, 1965) with reagents produced by bioMérieux except for the decolorizer which was substituted by $96 \%(\mathrm{v} / \mathrm{v})$ ethanol. Acid-fastness was determined by Ziehl-Neelsen staining (Lanyi, 1987).

Tolerance to $\mathrm{NaCl}$ between 2 and $14 \%(\mathrm{w} / \mathrm{v})$ was tested on $\mathrm{R}$ medium. The influence of temperature on growth was examined on $\mathrm{R}$ medium between 5 and $45^{\circ} \mathrm{C}$. Oxygen requirements were determined on $R$ medium using the Generbag microaer and Generbag anaer incubation systems (bioMérieux). Acid production from carbohydrates was proven by the method of Hugh \& Leifson (1953), as modified by Gledhill \& Casida (1969). Utilization of organic acids was studied using the media described by Gordon \& Mihm (1957) and Cowan \& Steel (1965) by adding the sodium salts of the organic acids to a final concentration of $0.2 \%$. In the tartrate-containing medium, the sodium salt was replaced by the potassium salt. Decomposition of adenine, hypoxanthine, xanthine and tyrosine was determined by using the method of Gordon et al. (1974). Nitrate reduction, urease activity, indole production, hydrogen sulphide production, hydrolysis of Tween 80 , aesculin, gelatin, methyl red and Voges-Proskauer reactions were examined as described by Lanyi (1987). Reagents NIT 1 and NIT 2 (bioMérieux) were used for testing nitrate reduction. Indole production, methyl red and Voges-Proskauer reactions were examined by using Kovács' reagent, VP 1 and VP 2 (bioMérieux), respectively. Hydrogen sulphide production was demonstrated with Bacto- $\mathrm{H}_{2} \mathrm{~S}$ test strips (Difco). Catalase production and hydrolysis of casein and potato starch were tested by the methods of Gledhill \& Casida (1969). Cytochrome oxidase was proven using DrySlide oxidase test strips (Difco). Hydrolysis of hippurate was examined as described by Cowan \& Steel (1965). Susceptibility to antibiotics was tested by placing antibiotic discs (bioMérieux) on $\mathrm{R}$ medium agar plates seeded with a suspension of the strain.

In addition, the ability to utilize 95 carbon sources was tested by using GP-microplates of the Biolog identification system described by Bochner (1989) and Bochner \& Savageau (1977). Utilization of different substrates for respiration (formation of NADH) was examined by strains after cultivation on Biolog Universal Growth Medium for $2 \mathrm{~d}$ at $28^{\circ} \mathrm{C}$. Enzyme activities of a 24 -h-old culture on $\mathrm{R}$ medium were studied with the API ZYM system (bioMérieux). Culture samples $(100 \mu \mathrm{l})$ were transferred onto the API ZYM strips and incubated at $37^{\circ} \mathrm{C}$ for $4 \mathrm{~h}$. Evaluation was carried out as recommended by the manufacturer.

Chemotaxonomic characterization. meso-Diaminopimelic acid (meso-A $\mathrm{A}_{2} \mathrm{pm}$ ) in whole-cell hydrolysates (Hasegawa et al., 1983) was identified by paper chromatography according to Rhuland et al. (1955). Cellular fatty acid methyl esters obtained from cells grown in TSB for $24 \mathrm{~h}$ at $28^{\circ} \mathrm{C}$ by the method described by Korn-Wendisch et al. (1989) were separated by GC (Groth et al., 1996) and identified as described previously (Schumann et al., 1997). Mycolic acids were analysed by HPLC after derivatization with $p-\alpha$ dibromoacetophenone as described by Butler et al. (1986). Menaquinones were analysed by HPLC as described by Collins et al. (1977) and Groth et al. (1996).

DNA base composition, DNA-DNA hybridization and ribotyping. DNA was isolated from 48-h-old cells grown in M 79 medium with the addition of $1 \%(\mathrm{w} / \mathrm{v})$ glycine at $28^{\circ} \mathrm{C}$ and with Puregene total-DNA-kit (Biozym). The $\mathrm{G}+\mathrm{C}$ content was determined by HPLC of deoxyribonucleosides by using the method of Mesbah et al. (1989). For DNA-DNA 
hybridization, previously described methods were used (Martin et al., 1997). Ribotyping of strains HKI 0134, HKI $0136^{\mathrm{T}}$, HKI 0144, HKI 0147, HKI 0149 and HKI 0150 was performed as described by Vuorio et al. (1999). Analysis was done with the RiboPrinter Microbial Characterization system (Qualicon).

16S rDNA sequence determination and phylogenetic analysis. Genomic DNA extraction, PCR-mediated amplification of $16 \mathrm{~S}$ rDNA, sequencing of the PCR products and determination of the phylogenetic position were described previously (Groth et al., 1996). The phylogenetic dendrogram was constructed from evolutionary distance values by the neighbour-joining method (Rainey et al., 1996).

Nucleotide sequence accession numbers. Accession numbers of sequences of type strains used for comparison are indicated in Fig. 3.

\section{RESULTS}

\section{Morphological and cultivation characteristics}

Twelve strains were isolated from tar-contaminated soil by enrichment culture techniques using hexadecane as sole carbon source. All isolates were highly similar to each other with respect to morphological and phenotypic properties. They formed circular and smooth colonies that were orange to orange-red coloured with shiny surfaces. Strains grew well on agar media and in liquid shaken cultures on $\mathrm{R}$ medium, $\mathrm{M}$ 79 or TSB. Occasionally, rough colonies were also observed. The diameter of colonies was $0 \cdot 2-2 \cdot 0 \mathrm{~mm}$. On malt extract agar, the surface was slimy and bright. Cells were Gram-positive, non-acid-fast, non-motile, short rod-shaped or coccoid. In 24-h-old cultures, dimensions of rods were $0.5-0.9 \mu \mathrm{m}$ by $1.0-2 \cdot 3 \mu \mathrm{m}$. Cells occurred singly, in pairs or in small clusters, in short flexible chains and very often in a typical coryneform V-shape (Fig. 1a). In 48-h-old cultures, cells were shorter and rods were $0 \cdot 8-1 \cdot 0 \mu \mathrm{m}$ by $0.7-$

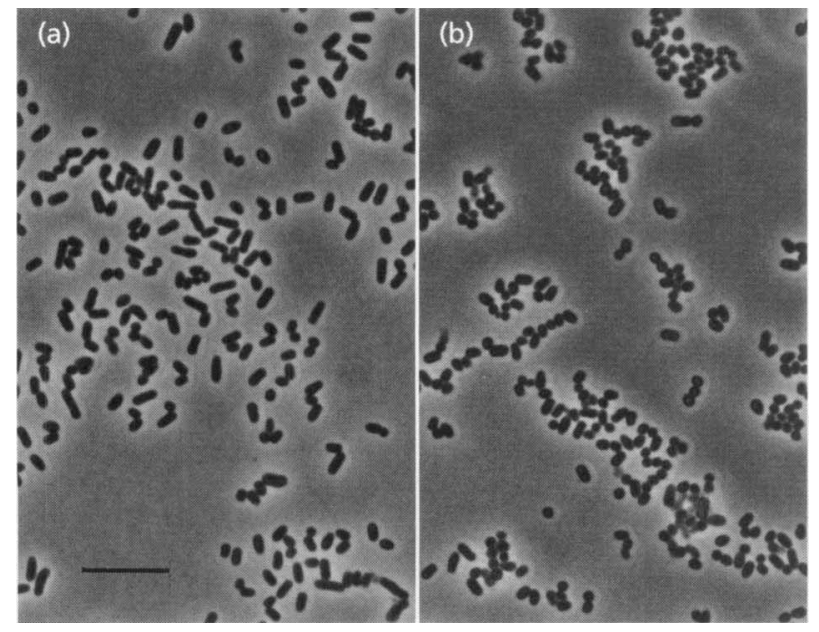

Fig. 1. Micrograph of strain HKI $0136^{\top}$ grown in liquid organic medium $\mathrm{M} 79$ for $24 \mathrm{~h}$ (a) and for $48 \mathrm{~h}(\mathrm{~b})$ at $28^{\circ} \mathrm{C}$. Bar, $10 \mu \mathrm{m}$.

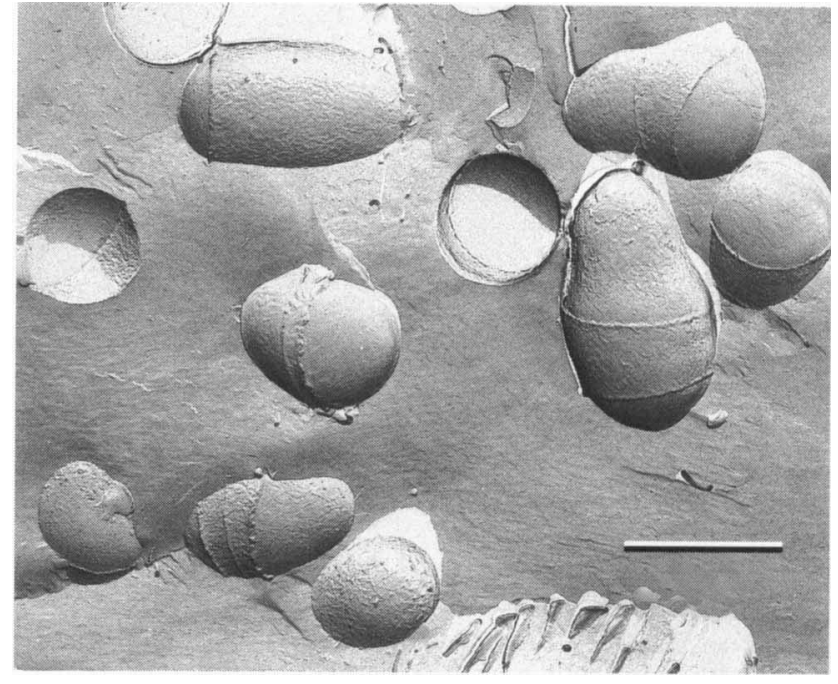

Fig. 2. Freeze-fracture electron micrograph of cells from a 48-hold culture of strain HKI $0136^{\top}$ grown in liquid organic medium $\mathrm{M} 79$ at $28^{\circ} \mathrm{C}$. Bar, $1 \mu \mathrm{m}$.

$1.3 \mu \mathrm{m}$ (Fig. 1b). Rod-coccus growth cycles were observed at $48 \mathrm{~h}$ intervals. In stationary cultures, rods fragmented into coccoid elements. Freeze-fracture electron microscopy of strain HKI $0136^{\mathrm{T}}$ revealed the belt-like zones surrounding the cells with different density and width (Fig. 2). The belts were bordered by band-like swellings on the plasma-sided fracture face which were formed in the process of cell fission.

Strains grew well aerobically on complex organic media at $28^{\circ} \mathrm{C}$ (tolerance $13-40^{\circ} \mathrm{C}$ ). No growth occurred at 5 or $42^{\circ} \mathrm{C}$. On R medium, cells grew in the presence of up to $6 \%(\mathrm{w} / \mathrm{v}) \mathrm{NaCl}$; higher salt concentrations reduced the growth and no growth was observed at $12 \%(\mathrm{w} / \mathrm{v}) \mathrm{NaCl}$. Growth occurred under microaerophilic, but not under anaerobic conditions at $28^{\circ} \mathrm{C}$.

\section{Physiological characteristics}

All isolates and also the tested type strains of $G$. amarae, G. hirsuta, G. hydrophobica, G. rubropertincta and $G$. terrae were catalase-positive and oxidasenegative. Growth of all isolates and tested type strains in the presence of 2 and $4 \%(\mathrm{w} / \mathrm{v}) \mathrm{NaCl}$ was positive; no growth occurred in the presence of 12 and $14 \%$ $(\mathrm{w} / \mathrm{v}) \mathrm{NaCl}$. None of the strains grew at 5 or $45^{\circ} \mathrm{C}$, but all grew well at $28^{\circ} \mathrm{C}$. Their ability to utilize a narrow range of carbon sources was demonstrated by the classical method of Hugh \& Leifson (1953) (Table 1) as well as by the microplate assay of the Biolog system (Table 2). In Table 1, the differentiating physiological properties of the twelve strains and type strains of selected species of the genus Gordonia, investigated in parallel tests, are listed. Acid was produced from D-fructose, while no acid was produced from L- 
Table 1. Differentiating morphological characteristics and physiological properties of Gordonia alkanivorans and selected type strains of species of the genus Gordonia

Strains: 1, G. alkanivorans (12 strains); 2, G. amarae; 3, G. hirsuta; 4, G. hydrophobica; 5, G. rubropertincta; 6, G. terrae. -, Negative; + , positive; w, weakly positive.

\begin{tabular}{|c|c|c|c|c|c|c|}
\hline Characteristic & $1 *$ & 2 & 3 & 4 & 5 & 6 \\
\hline Colour of colonies & $\begin{array}{l}\text { Orange to } \\
\text { orange-red }\end{array}$ & $\begin{array}{l}\text { Tannish to } \\
\text { white }\end{array}$ & $\begin{array}{c}\text { White to light } \\
\text { yellow }\end{array}$ & $\begin{array}{l}\text { Tannish to } \\
\text { white }\end{array}$ & Pink to red & Red \\
\hline Morphology & Rod-shaped & $\begin{array}{l}\text { Filaments } \\
\text { without } \\
\text { branching }\end{array}$ & Rod-shaped & Rod-shaped & Rod-shaped & Rod-shaped \\
\hline \multicolumn{7}{|l|}{ Acid production from: } \\
\hline D-Galactose & 0 & - & + & - & - & - \\
\hline D-Glucose & 0 & - & + & - & + & - \\
\hline Glycerol & 67 & + & + & - & + & - \\
\hline Inulin & 8 & - & + & - & - & - \\
\hline D-Mannitol & 92 & + & - & - & + & + \\
\hline D-Mannose & 0 & - & + & - & - & - \\
\hline L-Rhamnose & 0 & + & - & - & - & + \\
\hline D-Ribose & 17 & - & + & - & - & + \\
\hline Saccharose & 100 & + & + & - & + & + \\
\hline Salicin & 0 & w & - & - & - & + \\
\hline D-Sorbitol & 92 & - & - & - & + & + \\
\hline Trehalose & 8 & + & + & - & - & + \\
\hline \multicolumn{7}{|l|}{ Utilization of: } \\
\hline cis-Aconitate & 100 & - & - & + & - & + \\
\hline Benzoate & 100 & - & - & + & + & + \\
\hline Citrate & 100 & - & - & + & + & + \\
\hline Formate & 100 & w & - & + & w & + \\
\hline Hexadecane & 83 & - & + & + & + & + \\
\hline Hexadecene & 83 & - & - & + & + & - \\
\hline Hippurate & 0 & - & - & + & - & - \\
\hline Lactate & 8 & + & + & - & - & + \\
\hline Malate & 83 & + & - & + & + & + \\
\hline Succinate & 100 & + & - & + & + & + \\
\hline Propionate & 100 & + & - & + & + & + \\
\hline \multicolumn{7}{|l|}{ Decomposition of: } \\
\hline Aesculin & 0 & + & - & - & - & + \\
\hline Potato starch & 100 & - & - & - & + & - \\
\hline Urea & 100 & + & - & - & + & + \\
\hline \multicolumn{7}{|l|}{$\begin{array}{l}\text { Growth in presence of } \\
\mathrm{NaCl} \text { : }\end{array}$} \\
\hline $6 \%$ & 100 & - & - & + & + & + \\
\hline $8 \%$ & 83 & - & - & + & + & + \\
\hline $10 \%$ & $w$ & - & - & $\mathrm{w}$ & $\mathrm{w}$ & w \\
\hline \multicolumn{7}{|l|}{ Growth on $\mathbf{R}$ medium at: } \\
\hline $13^{\circ} \mathrm{C}$ & 100 & - & + & + & + & + \\
\hline $37^{\circ} \mathrm{C}$ & 100 & - & + & + & + & + \\
\hline $40^{\circ} \mathrm{C}$ & 100 & - & - & - & + & - \\
\hline $42{ }^{\circ} \mathrm{C}$ & 0 & - & - & - & + & - \\
\hline \multicolumn{7}{|l|}{ Antibiotic susceptibility: } \\
\hline Ampicillin $(10 \mu \mathrm{g})$ & 100 & + & + & + & + & - \\
\hline Erythromycin $(15 \mu \mathrm{g})$ & 8 & + & + & + & + & + \\
\hline Lincomycin $(2 \mu \mathrm{g})$ & 0 & - & $\mathrm{w}$ & - & - & - \\
\hline Nitrofuran $(100 \mu \mathrm{g})$ & 100 & + & + & + & + & - \\
\hline Oxacillin $(5 \mu \mathrm{g})$ & 17 & + & w & - & - & - \\
\hline Penicillin G (10 IU) & 42 & + & + & + & + & - \\
\hline Polymyxin B (300 IU) & w & + & w & - & - & - \\
\hline Sulfonamide $(250 \mu \mathrm{g})$ & 100 & $\mathrm{w}$ & $\mathrm{w}$ & + & $\mathrm{w}$ & $\mathrm{w}$ \\
\hline
\end{tabular}

* Values are the percentages of the 12 strains tested that are positive. 
Table 2. Differentiating characteristics of G. alkanivorans and selected species of the genus Gordonia determined by the Biolog system

Strains: 1, G. alkanivorans (12 strains); 2, G. aichiensis; 3, G. amarae; 4, G. bronchialis; 5, G. hirsuta; 6, G. hydrophobica; 7, G. rubropertincta; 8, G. sputi; 9, G. terrae. +, Positive; -, negative.

\begin{tabular}{|c|c|c|c|c|c|c|c|c|c|}
\hline Carbon source & $1^{*}$ & $2 \dagger$ & 3 & 4 & 5 & 6 & 7 & 8 & 9 \\
\hline$\alpha$-Cyclodextrin & 50 & - & - & + & - & - & - & - & - \\
\hline$\beta$-Cyclodextrin & 100 & - & - & + & - & - & + & - & - \\
\hline Dextrin & 67 & + & - & + & + & + & + & + & - \\
\hline Glycogen & 8 & - & - & + & - & - & + & - & - \\
\hline$N$-Acetylglucosamine & 0 & - & - & - & - & + & - & - & - \\
\hline Amygdalin & 0 & -- & - & - & - & + & - & - & - \\
\hline D-Arabitol & 0 & - & - & - & - & - & + & + & - \\
\hline Maltose & 0 & + & + & + & + & - & + & + & - \\
\hline Maltotriose & 0 & - & - & + & - & - & - & - & - \\
\hline D-Mannose & 75 & + & + & + & + & - & + & + & + \\
\hline 3-Methyl glucose & 0 & - & - & + & + & - & - & - & - \\
\hline Palatinose & 0 & - & - & + & - & - & - & - & - \\
\hline D-Raffinose & 0 & - & - & + & - & - & - & - & - \\
\hline L-Rhamnose & 0 & - & - & - & - & - & - & - & + \\
\hline D-Ribose & 8 & - & - & - & - & - & - & - & + \\
\hline Salicin & 0 & + & - & + & - & - & - & + & + \\
\hline D-Sorbitol & 17 & - & - & - & - & - & - & - & - \\
\hline D-Trehalose & 58 & + & + & - & + & + & + & + & + \\
\hline Turanose & 58 & + & - & + & + & - & + & + & + \\
\hline D-Xylose & 0 & - & - & + & - & - & + & - & + \\
\hline Acetic acid & 100 & - & + & - & + & + & + & - & + \\
\hline$\alpha$-Hydroxybutyric acid & 73 & - & - & - & - & + & + & + & + \\
\hline$\beta$-Hydroxybutyric acid & 100 & + & - & - & - & + & + & + & - \\
\hline$\alpha$-Ketoglutaric acid & 0 & - & - & - & - & - & + & - & - \\
\hline$\alpha$-Ketovaleric acid & 92 & + & - & - & - & + & + & + & + \\
\hline D-Lactic acid methyl ester & 33 & + & - & - & - & - & + & + & + \\
\hline L-Lactic acid & 0 & - & - & + & - & - & - & - & - \\
\hline L-Malic acid & 0 & - & - & - & - & + & - & - & - \\
\hline Methyl succinate & 0 & - & - & + & - & - & - & - & - \\
\hline Propionic acid & 25 & - & - & - & - & + & - & - & - \\
\hline Succinamic acid & 0 & - & - & - & - & - & - & - & + \\
\hline $\mathrm{N}$-Acetyl-L-glutamic acid & 100 & + & - & + & + & + & + & + & + \\
\hline Alaninamide & 42 & + & - & - & - & - & + & + & + \\
\hline L-Alanine & 0 & - & - & - & - & - & + & - & - \\
\hline Glycerol & 33 & + & - & - & - & - & + & + & - \\
\hline
\end{tabular}

*Values are the percentages of the 12 strains tested that are positive.

$\dagger$ Data from Database release 3.50 (Biolog).

arabinose, D-cellobiose, dextrin, lactose, maltose, Draffinose, starch and D-xylose. The following substrates were used by some isolates as sole carbon source: glycerol, inulin, D-mannitol, D-ribose, D-sorbitol and trehalose (Table 1). All tested strains utilized acetate and pyruvate. Oxalate and tartrate were not utilized. Nitrate was reduced and Tween 80 was hydrolysed. Adenine, casein, gelatin, hypoxanthine, tyrosine and xanthine were not decomposed. All tested strains were positive for formation of $\mathrm{H}_{2} \mathrm{~S}$, whereas they were negative for production of indole, the VogesProskauer test and the methyl red test. All strains listed in Table 1 were susceptible to the following antibiotics: chloramphenicol $(30 \mu \mathrm{g})$, ciprofloxacin $(5 \mu \mathrm{g})$, gentamicin $(10 \mu \mathrm{g})$, kanamycin $(30 \mu \mathrm{g})$, neomycin $(30 \mu \mathrm{g})$, oxytetracycline $(30 \mu \mathrm{g})$, rifampicin $(30 \mu \mathrm{g})$ and streptomycin $(10 \mu \mathrm{g})$, but were resistant to lincomycin $(2 \mu \mathrm{g})$. All isolated strains grew on solid medium ISP 9 (Shirling \& Gottlieb, 1966) with $1 \%(\mathrm{v} / \mathrm{v})$ ethanol as the sole carbon source. Growth with $0.5 \%$ humic acid (Aldrich) was positive only in the presence of $0.1 \%$ glucose. Growth of tar soil isolates occurred on ISP 9 medium supplemented with $0.2 \%$ lignin (Aldrich), whereas growth with $0.5 \%$ cellulose (Aldrich) was poor. The isolates utilized $0.1 \%$ phenol in the presence of $0.1 \%$ glucose. In contrast, the type strain of $G$. 
Table 3. Chemotaxonomic characteristics of strains isolated from tar-contaminated soil and of type strains of selected Gordonia species

\begin{tabular}{|c|c|c|c|c|c|c|c|c|c|c|c|c|}
\hline \multirow[t]{2}{*}{ Strain } & \multirow{2}{*}{$\begin{array}{c}\mathrm{G}+\mathrm{C} \\
(\mathrm{mol} \%)\end{array}$} & \multirow{2}{*}{$\begin{array}{c}\text { Menaquinone (peak } \\
\text { area ratio) }\end{array}$} & \multicolumn{10}{|c|}{ Cellular fatty acids (\%) } \\
\hline & & & $C_{12: 0}$ & $C_{14: 0}$ & $C_{16: 0}$ & $C_{16: 1}$ & $t_{17}{ }^{*}$ & $C_{17: 0}$ & $C_{17: 1}$ & $C_{18: 0}$ & $\mathrm{C}_{18: 1}$ & $t_{19^{\dagger}}^{\dagger}$ \\
\hline HKI 0144 & 68 & $9 \mathrm{H}_{2}, 8 \mathrm{H}_{2}, 7 \mathrm{H}_{2}(82: 7: 2)$ & & 30 & $31 \cdot 8$ & $23 \cdot 0$ & $1 \cdot 2$ & & $1 \cdot 1$ & 1.4 & $25 \cdot 0$ & $12 \cdot 3$ \\
\hline HKI 0145 & 68 & $9 \mathrm{H}_{2}, 8 \mathrm{H}_{2}, 7 \mathrm{H}_{2}(82: 6: 2)$ & 1.9 & $3 \cdot 3$ & $29 \cdot 7$ & $22 \cdot 5$ & $6 \cdot 3$ & & & & $23 \cdot 5$ & $11 \cdot 0$ \\
\hline HKI 0146 & 68 & $9 \mathrm{H}_{2}, 8 \mathrm{H}_{2}, 9(88: 4: 1)$ & $6 \cdot 4$ & $5 \cdot 5$ & $30 \cdot 7$ & $28 \cdot 9$ & & & & & 16.9 & $11 \cdot 5$ \\
\hline HKI 0134 & 68 & $9 \mathrm{H}_{2}, 8 \mathrm{H}_{2}, 7 \mathrm{H}_{2}(82: 4: 2)$ & & $3 \cdot 9$ & $32 \cdot 5$ & $21 \cdot 6$ & & $1 \cdot 5$ & & $2 \cdot 8$ & $27 \cdot 5$ & 8.7 \\
\hline HKI 0135 & 68 & $9 \mathrm{H}_{2}^{2}, 8 \mathrm{H}_{2}^{2}, 7 \mathrm{H}_{2}^{2}(81: 6: 2)$ & & $2 \cdot 8$ & $33 \cdot 8$ & $23 \cdot 5$ & & & & 1.5 & $25 \cdot 4$ & $11 \cdot 9$ \\
\hline HKI $0136^{\mathrm{T}}$ & 68 & $9 \mathrm{H}_{2}, 8 \mathrm{H}_{2}, 7 \mathrm{H}_{2}(83: 6: 2)$ & & $3 \cdot 9$ & $31 \cdot 3$ & $19 \cdot 9$ & & & & 2.4 & $24 \cdot 5$ & 8.8 \\
\hline HKI 0148 & 67 & $9 \mathrm{H}_{2}, 8 \mathrm{H}_{2}, 7 \mathrm{H}_{2}(82: 6: 2)$ & & $2 \cdot 4$ & $33 \cdot 0$ & $24 \cdot 7$ & & & & & $26 \cdot 6$ & $13 \cdot 2$ \\
\hline HKI 0149 & 68 & $9 \mathbf{H}_{2}, 8 \mathbf{H}_{2}, 7 \mathbf{H}_{2}(81: 6: 2)$ & $1 \cdot 7$ & $2 \cdot 8$ & $31 \cdot 7$ & $23 \cdot 0$ & & & & & $25 \cdot 3$ & $12 \cdot 2$ \\
\hline HKI 0150 & 68 & $9 \mathrm{H}_{2}, 8 \mathrm{H}_{2}, 7 \mathrm{H}_{9}(85: 7: 1)$ & & $4 \cdot 7$ & $36 \cdot 1$ & $23 \cdot 7$ & & & & $2 \cdot 3$ & $26 \cdot 3$ & 6.9 \\
\hline G. rubropertincta DSM $43197^{\text {T }}$ & $67-69 t$ & $9 \mathrm{H}_{n} \pm$ & & 3.4 & $33 \cdot 7$ & $23 \cdot 4$ & & & & & $27 \cdot 8$ & $9 \cdot 3$ \\
\hline$G$, terrae DSM $43249^{\mathrm{T}}$ & $64-69+$ & $9 \mathrm{H}_{2}^{2+}$ & $2 \cdot 0$ & $2 \cdot 9$ & 34.5 & $21 \cdot 4$ & & & & & 26.9 & $10 \cdot 6$ \\
\hline G. amarae DSM $43392^{\mathrm{T}}$ & $60-66 \S$ & $9 \mathrm{H}_{2}^{2+} \S$ & & $4 \cdot 1$ & 34.7 & $24 \cdot 1$ & & & & & $33 \cdot 1$ & \\
\hline G. hirsuta DSM $44140^{\mathrm{T}}$ & $69 \|$ & $9 \mathrm{H}_{2}^{20} \|$ & & $2 \cdot 3$ & $32 \cdot 8$ & 13.7 & & & & $6 \cdot 5$ & $38 \cdot 4$ & $6 \cdot 4$ \\
\hline G. hydrophobica DSM $44015^{\mathrm{T}}$ & $69 \uparrow$ & $9 \mathrm{H}_{2}^{2} \mathrm{~T}$ & $1 \cdot 1$ & $2 \cdot 5$ & $33 \cdot 6$ & $20 \cdot 0$ & & $1 \cdot 2$ & $3 \cdot 0$ & $1 \cdot 1$ & $26 \cdot 5$ & $8 \cdot 3$ \\
\hline
\end{tabular}

$* t_{17}, 10$-Methyl hexadecanoic acid.

$\dagger t_{19}, 10$-Methyl octadecanoic acid.

$\ddagger$ Data from Goodfellow (1986).

$\S$ Data from Klatte et al. (1994).

|| Data from Klatte et al. (1996).

I Data from Bendinger et al. (1995).

rubropertincta grew well on phenol-containing media without glucose.

In Table 2, only those results of metabolic properties (Biolog analysis) which were neither positive nor negative for all isolated and type strains are indicated. All strains investigated were positive for utilization of the following substrates as sole carbon source: Tween 40 and 80 , D-fructose, $\alpha$-D-glucose, D-psicose, saccharose, methyl pyruvate and pyruvic acid. None of the tested strains utilized the following substrates: inulin, mannan, $\mathrm{N}$-acetylmannosamine, L-arabinose, arbutin, cellobiose, L-fucose, D-galactose, D-galacturonic acid, gentiobiose, D-gluconic acid, $m$-inositol, $\alpha$-D-lactose, lactulose, D-mannitol, D-melezitose, Dmelibiose, methyl $\alpha$-D-galactoside, methyl $\beta$-Dgalactoside, methyl $\alpha$-D-glucoside, methyl $\beta$-D-glucoside, methyl $\alpha$-mannoside, sedoheptulosan, stachyose, D-tagatose, xylitol, $\gamma$-hydroxybutyric acid, $p$-hydroxyphenylacetic acid, lactamide, D-malic acid, succinic acid, D-alanine, L-alanyl-glycine, L-asparagine, Lglutamic acid, glycyl-L-glutamic acid, L-pyroglutamic acid, L-serine, putrescine, 2,3-butanediol, adenosine, 2 -deoxyadenosine, inosine, thymidine, uridine, AMP, TMP, UMP, fructose 6-phosphate, glucose 1-phosphate, glucose 6-phosphate and DL- $\alpha$-glycerol phosphate. Only two isolates $(17 \%)$ were able to utilize Dsorbitol. In contrast to the type strain of G. rubropertincta, isolated strains did not use glycogen, Darabitol, maltose, D-xylose, $\alpha$-ketoglutaric acid and Lalanine as sole carbon source, but $\alpha$-cyclodextrin was used (Table 2). Activities of selected enzymes were analysed by the API ZYM method (bioMérieux). By this semiquantitative method, 19 enzymic activities were examined. The isolated strains, as well as the type strains of $G$. rubropertincta and $G$. terrae, were: positive for the enzymes alkaline phosphatase, esterase (C4), esterase lipase (C8), leucine arylamidase, cystine arylamidase and $\alpha$-glucosidase; and weakly positive for the enzymes lipase (C14), valine arylamidase, trypsin, acid phosphatase, naphthol-AS-BI-phosphohydrolase and $\beta$-glucosidase. Strains were negative for the enzymes chymotrypsin, $\alpha$-galactosidase, $\beta$-galactosidase, $\beta$-glucuronidase, $N$-acetyl- $\beta$-glucosaminidase, $\alpha$-mannosidase and $\alpha$-fucosidase.

\section{Chemotaxonomic characteristics}

All isolates studied possessed meso- $\mathrm{A}_{2} \mathrm{pm}$, mycolic acids, $\mathrm{MK}-9\left(\mathrm{H}_{2}\right)$ as predominating menaquinone, and straight-chain saturated and unsaturated cellular fatty acids with mainly 16 and 18 carbon atoms as well as tuberculostearic acid (10-methyl octadecanoic acid) (Table 3). HPLC analysis of mycolic acid $p$-bromophenacyl esters revealed the occurrence of three components with retention times between 21.4 and $23.3 \mathrm{~min}$ in all isolates examined. Strain HKI 0150 showed an additional minor component eluting after $20.5 \mathrm{~min}$ (Table 4). On average, retention times of type strains of Gordonia species were slightly higher ( $G$. terra, G. rubropertincta) or significantly higher ( $G$. bronchialis, G. aichiensis, G. sputi) than those of the isolates. The $\mathrm{G}+\mathrm{C}$ composition of strain HKI 0148 was $67 \mathrm{~mol} \%$, while all other isolates showed a $\mathrm{G}+\mathrm{C}$ value of $68 \mathrm{~mol} \%$ (Table 3 ). 
Table 4. HPLC-elution profiles of mycolic acid p-bromophenacyl esters of strains isolated from tar-contaminated soil and of selected type strains of the suborder Corynebacterineae

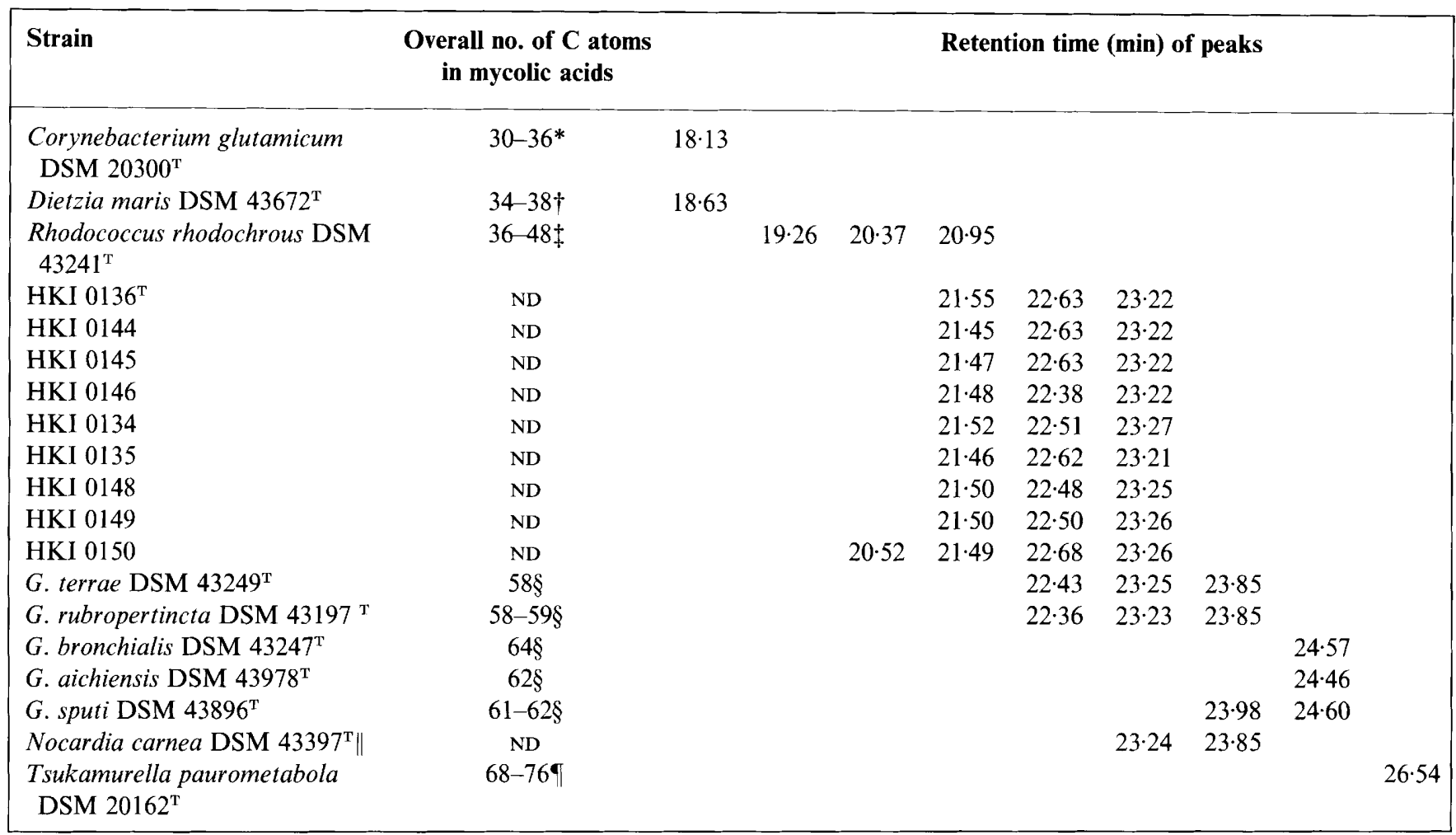

ND, Not determined.

* Data from Collins et al. (1982).

$\uparrow$ Data from Rainey et al. (1995).

\$Data from Azuma et al. (1974).

$\S$ Data from Klatte et al. (1994).

$\|$ Mycolic acids of $N$. carnea similar to those of G. amarae (Lechevalier \& Lechevalier, 1974) containing 46-54 carbon atoms (Klatte et al., 1994).

If Data from Collins \& Jones (1982).

\section{$16 S$ rDNA sequence analysis}

Partial 16S rDNA sequences of about $530 \mathrm{nt}$ were determined for six isolated strains, HKI 0134, HKI 0136 ${ }^{\mathrm{T}}$, HKI 0144, HKI 0147, HKI 0149 and HKI 0150 . As all these sequences showed $100 \%$ identity, the almost complete $16 \mathrm{~S}$ rDNA sequence, comprising $1490 \mathrm{nt}$ ( $97.7 \%$ of the Escherichia coli sequence), was determined for one of these strains, strain HKI $0136^{\mathrm{T}}$. Comparison with the database of members of the class Actinobacteria revealed the highest degree of similarity with type strains of species of the genus Gordonia $(96 \cdot 2-99 \cdot 1 \%)$. Strain HKI $0136^{\mathrm{T}}$ is closely related to $G$. rubropertincta DSM $43197^{\mathrm{T}}$, sharing $99.1 \%$ sequence similarity. The phylogenetic dendrogram shown in Fig. 3 was constructed from evolutionary distance values by the neighbour-joining method. Low to moderate bootstrap values indicated that most branching points have little statistical significance. Information on the phylogenetic position of strain HKI
$0136^{\mathrm{T}}$ guided the selection of type strains for tests of phenotypic properties.

\section{DNA-DNA homology}

The DNA-DNA homology between strain HKI $0136^{\mathrm{T}}$ and the type strain G. rubropertincta DSM $43197^{\mathrm{T}}$ was $52 \%$.

\section{Ribotyping}

Six isolates, HKI 0134, HKI 0136 ${ }^{\mathrm{T}}$, HKI 0144, HKI 0147, HKI 0149, HKI 0150, as well as the type strains of $G$. rubropertincta and $G$. terrae were ribotyped with the restriction enzyme EcoRI. All strains possessed two bands of sizes 3 and $40-50 \mathrm{~kb}$ which are also present in species of Mycobacterium (Vuorio et al., 1999). Strain-specific discrimination was done on the basis of the presence of several additional bands ranging between 0.5 and $18 \mathrm{~kb}$ (not shown). All isolates from tar-contaminated soil produced a fragment of 


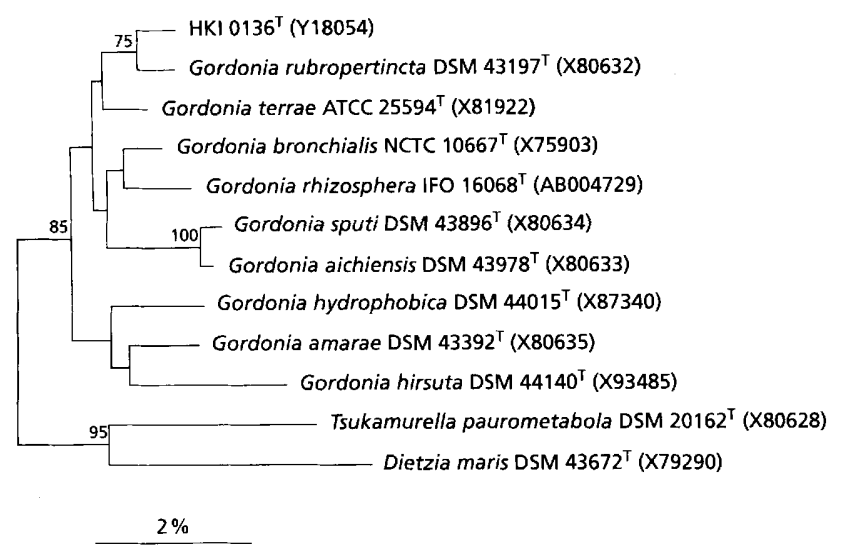

Fig. 3. Phylogenetic dendrogram based on the results of a $16 \mathrm{~S}$ rDNA sequence comparison. Numbers at branching points refer to bootstrap values ( 500 trees resampled). Scale bar, 2 inferred nucleotide substitutions per 100 nucleotides.

$8 \mathrm{~kb}$ which was absent in the type strains. These strains showed higher than $85 \%$ ribotype similarity among each other. Fragments of 15 and $18 \mathrm{~kb}$ were specific for G. terrae DSM $43249^{\mathrm{T}}$ and $G$. rubropertincta DSM $43197^{\mathrm{T}}$. These two strains showed lower than $70 \%$ ribotype similarity to the isolates.

\section{DISCUSSION}

It was the aim of this study to identify the taxonomic position of isolates from contaminated soil on the basis of chemotaxonomic, physiological and genetic characteristics. Analysis of $16 \mathrm{~S}$ rDNA, the presence of menaquinone type MK-9 $\left(\mathrm{H}_{2}\right)$ and retention times of mycolic acid $p$-bromophenacyl esters that were similar to those identified in members of the genus Gordonia revealed that the isolates were members of this genus. As a $16 \mathrm{~S}$ rDNA similarity value of $99 \cdot 1 \%$, determined for isolate HKI $0136^{\mathrm{T}}$ and the type strain of $G$. rubropertincta, does not exclude membership to the same species (Stackebrandt \& Goebel, 1994), DNADNA reassociation was carried out in order to determine the degree of relatedness at the genomic level. The value (52\% DNA similarity) was significantly below the threshold value of about $70 \%$ recommended for the delineation of species (Wayne $e t$ $a l ., 1987)$. Ribotyping indicated that all isolates were more similar to each other than to their phylogenetic neighbours. The occurrence of different ribotyping patterns among strains of a species is a well-documented observation (Kloos et al., 1997). The taxonomic distinctness of strain HKI $0136^{\mathrm{T}}$ and the other tar isolates from $G$. rubropertincta DSM $43197^{\mathrm{T}}$ was also verified at the chemotaxonomic level by differences in the retention times of mycolic acid derivatives. Although the precise number of carbon atoms was not determined, the differences in retention times between all isolates and the type strains of Gordonia species indicated differences in chain length.
As the number of carbon atoms of these type strains are known (Table 4), it can be concluded that the number of carbon atoms of the mycolic acids of the isolates ranges between about 55 and 57. Morphological, chemotaxonomic (Table 3) and 16S rDNA sequence data demonstrated that strain HKI $0136^{\mathrm{T}}$ belongs to the genus Gordonia. On the basis of the moderate DNA-DNA reassociation value obtained for strain HKI $0136^{\mathrm{T}}$ and its nearest phylogenetic neighbour, G. rubropertincta DSM $43197^{\mathrm{T}}$, the chain length of mycolic acids and the presence of a unique pattern of physiological and metabolic properties of strain HKI $0136^{\mathrm{T}}$ and relatives (Tables 1 and 2), we propose a new species of Gordonia, Gordonia alkanivorans sp. nov.

\section{Description of Gordonia alkanivorans sp. nov.}

Gordonia alkanivorans (al.ka.ni'vo.rans. M.L. n. alkanum saturated aliphatic hydrocarbon; $\mathrm{L}$. v. vorare to eat; L. adj. alkanivorans alkane-devouring).

Gram-positive, non-acid-fast, regular rod-shaped cells $(0.5-0.9 \times 1 \cdot 0-2.3 \mu \mathrm{m})$ occurring singly, in pairs, small clusters, in V-shape arrangement or in short chains. Non-motile. Mycelium absent. Rod-coccus growth cycle. Colonies orange to orange-red. Colony morphology either convex and smooth or rough and flat with irregular margins. When grown on hexadecane or hexadecene as sole carbon source the orange colour fades. Catalase-positive and oxidase-negative. Acid production observed from fructose, glycerol, D-mannitol, saccharose and D-sorbitol, but not from Dglucose. The alkali salts acetate, aconitate, benzoate, citrate, formate, malate, succinate, propionate and pyruvate were used for growth, but lactate, oxalate and tartrate were not utilized. Nitrogenous compounds like ammonia, nitrate and urea were utilized. Tween 80 and potato starch were hydrolysed. Aesculin, casein, adenine, gelatin, hippurate, hypoxanthine, tyrosine and xanthine were not decomposed. Formation of $\mathrm{H}_{2} \mathrm{~S}$ was positive, whereas production of indole, the Voges-Proskauer test and the methyl red test were negative. Susceptible to the antibiotics ampicillin $(10 \mu \mathrm{g})$, chloramphenicol $(30 \mu \mathrm{g})$, ciprofloxacin $(5 \mu \mathrm{g})$, gentamicin $(10 \mu \mathrm{g})$, kanamycin $(30 \mu \mathrm{g})$, neomycin $(30 \mu \mathrm{g})$, nitrofuran $(100 \mu \mathrm{g})$, oxytetracycline $(30 \mu \mathrm{g})$, rifampicin $(30 \mu \mathrm{g})$, streptomycin $(10 \mu \mathrm{g})$ and sulfonamide $(250 \mu \mathrm{g})$, but weakly susceptible to erythromycin $(15 \mu \mathrm{g})$, oxacillin $(5 \mu \mathrm{g})$, penicillin G (10 IU), polymycin B (300 IU). Resistant to lincomycin $(2 \mu \mathrm{g})$. The following carbon substrates were not utilized: glycogen, D-arabitol, maltose, D-xylose, $\alpha$-ketoglutaric acid and L-alanine, but $\alpha$-cyclodextrin, $\beta$-cyclodextrin, dextrin, D-mannose, $\mathrm{D}$-trehalose, turanose, acetic acid, $\alpha$-hydroxybutyric acid, $\beta$-hydroxybutyric acid, $\alpha$-ketovaleric acid, $N$-acetyl-L-glutamic acid, Tween 40 and 80 , D-fructose, $\alpha$-D-glucose, D-psicose, saccharose, methyl pyruvate and pyruvic acid were utilized. The cell wall contains meso- $\mathrm{A}_{2} \mathrm{pm}$ as the diagnostic diamino acid. The predominant isoprenologue is MK- 
$9\left(\mathbf{H}_{2}\right)$; minor amounts of MK-8( $\left.\mathbf{H}_{2}\right)$ are also present. Contains major amounts of straight-chain saturated and monounsaturated fatty acids and tuberculostearic acid. Mycolic acids with less than 60 carbon atoms are present. DNA $\mathrm{G}+\mathrm{C}$ content is $68 \mathrm{~mol} \%$. Isolated from contaminated soil sampled from the area of a former tar factory in Rositz (Germany). The type strain is HKI $0136^{\mathrm{T}}\left(=\mathrm{DSM} 44369^{\mathrm{T}}\right)$.

\section{ACKNOWLEDGEMENTS}

We thank Ina Kramer for performing the 16S rDNA sequence analysis and Jutta Burghardt for the DNA-DNA hybridization test (DSMZ, Braunschweig). We are grateful to $\mathrm{U}$. Westermann for carrying out freeze-fracturing techniques and electron microscopy (Institut für Ultrastrukturforschung des Klinikums der Friedrich-Schiller-Universität, Jena). This work was supported by grant B 303-95004 from the Ministry of Sciences, Research and Culture, Thuringia, Germany.

\section{REFERENCES}

Azuma, I., Ohuchida, A., Taniyama, T., Yamamura, Y., Shoji, K., Hori, M., Tanaka, Y. \& Ribi, E. (1974). The mycolic acids of Mycobacterium rhodochrous and Nocardia corallina. Biken J17, $1-7$.

Bendinger, B., Rainey, F. A., Kroppenstedt, R. M., Moormann, M. \& Klatte, S. (1995). Gordona hydrophobica sp. nov., isolated from biofilters for waste gas treatment. Int J Syst Bacteriol 45, 544-548.

Bochner, B. R. (1989). Sleuthing out bacterial identities. Nature 339, 157-158.

Bochner, B. R. \& Savageau, M. A. (1977). Generalized indicator plate for genetic, metabolic and taxonomic studies with microorganisms. Appl Environ Microbiol 33, 434 444.

Butler, W. R., Ahearn, D. G. \& Kilburn, J. O. (1986). Highperformance liquid chromatography of mycolic acids as a tool in the identification of Corynebacterium, Nocardia, Rhodococcus, and Mycobacterium species. J Clin Microbiol 23, 182-185.

Collins, M. D. \& Jones, D. (1982). Lipid composition of Corynebacterium paurometabolum (Steinhaus). FEMS Microbiol Lett 13, 13-16.

Collins, M. D., Pirouz, T., Goodfellow, M. \& Minnikin, D. E. (1977). Distribution of menaquinones in actinomycetes and corynebacteria. J Gen Microbiol 100, 221-230.

Collins, M. D., Goodfellow, M. \& Minnikin, D. E. (1982). A survey of the structures of mycolic acids in Corynebacterium and related taxa. J Gen Microbiol 128, 129-149.

Cowan, S. T. \& Steel, K. J. (1965). Manual for the Identification of Medical Bacteria. Cambridge: Cambridge University Press.

Gledhill, W. E. \& Casida, L. E., Jr (1969). Predominant catalasenegative soil bacteria. III. Agromyces, gen. n., microorganisms intermediary to Actinomyces and Nocardia. Appl Microbiol 18, 340-349.

Goodfellow, M. (1986). Genus Rhodococcus Zopf 1891. In Bergey's Manual of Systematic Bacteriology, vol. 2, pp. 1472-1481. Edited by P. H. A. Sneath, N. S. Mair, M. E. Sharpe \& J. G. Holt. Baltimore: Williams \& Wilkins.

Goodfellow, M. (1992). The family Nocardiacea. In The Prokaryotes, 2nd edn, pp. 1188-1213. Edited by A. Balows,
H. G. Trüper, M. Dworkin, W. Harder \& K.-H. Schleifer. New York: Springer.

Goodfellow, M. \& Alderson, G. (1977). The actinomycete-genus Rhodococcus: a home for the 'rhodochrous' complex. J Gen Microbiol 100, 99-122.

Gordon, R. E. \& Mihm, J. M. (1957). A comparative study of some strains received as nocardiae. $J$ Bacteriol 73, 15-27.

Gordon, R. E., Barnett, D. A., Handerhan, J. E. \& Pang, C. H.-N. (1974). Nocardia coeliaca, Nocardia autotrophica, and the nocardin strain. Int $J$ Syst Bacteriol 24, 54-63.

Groth, I., Schumann, P., Weiss, N., Martin, K. \& Rainey, F. A. (1996). Agrococcus jenensis gen. nov., sp. nov., a new genus of actinomycetes with diaminobutyric acid in the cell wall. Int $J$ Syst Bacteriol 46, 234-239.

Hasegawa, T., Takizawa, M. \& Tanida, S. (1983). A rapid analysis for chemical grouping of aerobic actinomycetes. $J$ Gen Appl Microbiol 29, 319-322.

Hayakawa, M. \& Nonomura, H. (1987). Humic acid-vitamin agar, a new medium for the selective isolation of soil actinomycetes. $J$ Ferment Technol 65, 501-509.

Hugh, R. \& Leifson, E. (1953). The taxonomic significance of fermentative versus oxidative metabolism of carbohydrates by various gram negative bacteria. J Bacteriol 66, 24-26.

Klatte, S., Rainey, F. A. \& Kroppenstedt, R. M. (1994). Transfer of Rhodococcus aichiensis Tsukamura 1982 and Nocardia amarae Lechevalier and Lechevalier 1974 to the genus Gordona as Gordona aichiensis comb. nov. and Gordona amarae comb. nov. Int $J$ Syst Bacteriol 44, 769-773.

Klatte, S., Kroppenstedt, R. M., Schumann, P., Altendorf, K. \& Rainey, F. A. (1996). Gordona hirsuta sp. nov. Int J Syst Bacteriol 46, 876-880.

Kloos, W. E., Ballard, D. N., Webster, J. A. \& 12 other authors (1997). Ribotype delineation and description of Staphylococcus sciuri subspecies and their potential as reservoirs of methicillin resistance and staphylolytic enzyme genes. Int $J$ Syst Bacteriol 47, 313-323.

Korn-Wendisch, F., Kempf, A., Grund, E., Kroppenstedt, R. M. \& Kutzner, H. J. (1989). Transfer of Faenia rectivirgula Kurup and Agre 1983 to the genus Saccharopolyspora Lacey and Goodfellow 1975, elevation of Saccharopolyspora hirsuta subsp. taberi Labeda 1987 to species level, and emended description of the genus Saccharopolyspora. Int J Syst Bacteriol 39, 430-441. Lanyi, B. (1987). Classical and rapid identification methods for medically important bacteria. Methods Microbiol 19, 1-67.

Lechevalier, M. P. \& Lechevalier, H. A. (1974). Nocardia amarae sp. nov., an actinomycete common in foaming activated sludge. Int J Syst Bacteriol 24, 278--288.

Martin, K., Schumann, P., Rainey, F. A., Schuetze, B. \& Groth, I. (1997). Janibacter limosus gen. nov., sp. nov., a new actinomycete with meso-diaminopimelic acid in the cell wall. Int $J$ Syst Bacteriol 47, 529-534.

Mesbah, M., Premachandran, U. \& Whitman, W. B. (1989). Precise measurement of the $\mathrm{G}+\mathrm{C}$ content of deoxyribonucleic acid by high-performance liquid chromatography. Int $J$ Syst Bacteriol 39, 159-167.

Prauser, H., Schumann, P., Rainey, F. A., Kroppenstedt, R. M. \& Stackebrandt, E. (1997). Terracoccus luteus gen. nov., sp. nov., an LL-diaminopimelic acid-containing coccoid actinomycete from soil. Int J Syst Bacteriol 47, 1218-1224.

Rainey, F. A., Klatte, S., Kroppenstedt, R. M. \& Stackebrandt, E. (1995). Dietzia, a new genus including Dietzia maris comb. nov., formerly Rhodococcus maris. Int J Syst Bacterio! 45, 32-36. 
Rainey, F. A., Ward-Rainey, N. L., Kroppenstedt, R. M. \& Stackebrandt, E. (1996). The genus Nocardiopsis represents a phylogenetically coherent taxon and a distinct actinomycete lineage: proposal of Nocardiopsiaceae fam. nov. Int $J$ Syst Bacteriol 46, 1088-1092.

Rhuland, L. E., Work, E., Denman, R. F. \& Hoare, D. S. (1955). The behaviour of the isomers of $\alpha, \varepsilon$-diaminopimelic acid on paper chromatograms. J Am Chem Soc 77, 4844-4846.

Riegel, P., Kamne-Fotso, M. V., De Briel, D., Prevost, G., Jehl, F., Piemont, Y. \& Monteil, H. (1994). Rhodococcus chubuensis Tsukamura 1982 is a later subjective synonym of Gordona sputi (Tsukamura 1978) Stackebrandt 1989 comb. nov. Int J Syst Bacteriol 44, 764-768.

Ruimy, R., Boiron, P., Boivin, V. \& Christen, R. (1994). A phylogeny of the genus Nocardia deduced from the analysis of smallsubunit ribosomal DNA sequences, including transfer of Nocardia amarae to the genus Gordona as Gordona amarae comb. nov. FEMS Microbiol Lett 123, 261-268.

Schumann, P., Prauser, H., Rainey, F. A., Stackebrandt, E. \& Hirsch, P. (1997). Friedmanniella antarctica gen. nov., sp. nov., an LL-diaminopimelic acid-containing actinomycete from Antarctic sandstone. Int Syst Bacteriol 47, 278--283.

Shirling, E. B. \& Gottlieb, D. (1966). Methods for characterization of Streptomyces species. Int J Syst Bacteriol 16, 313-340.

Stackebrandt, E. \& Goebel, B. M. (1994). A place for DNA-DNA reassociation and 16S rRNA sequence analysis in the present species definition in bacteriology. Int $J$ Syst Bacteriol 44, 846-849.

Stackebrandt, E., Smida, J. \& Collins, M. D. (1988). Evidence of phylogenetic heterogeneity within the genus Rhodococcus: revival of the genus Gordona (Tsukamura). J Gen Appl Microbiol 34, 341-348.

Stackebrandt, E., Rainey, F. A. \& Ward-Rainey, N. L. (1997). Proposal for a new hierarchic classification system, Actinobacteria classis nov. Int J Syst Bacteriol 47, 479-491.

Takeuchi, M. \& Hatano, K. (1998). Gordonia rhizosphera sp. nov. isolated from the mangrove rhizosphere. Int J Syst Bacteriol $\mathbf{4 8}$, 907-912.

Tsukamura, M. (1971). Proposal of a new genus, Gordona, for slightly acid-fast organisms occurring in sputa of patients with pulmonary disease and in soil. $J$ Gen Microbiol 68, 15-26.

Tsukamura, M. (1991). Some addenda on the species Gordona sputi (Tsukamura 1978) Stackebrandt et al. 1989 comb. nov. Int $J$ Syst Bacteriol 41, 569-570.

Tsukamura, M. \& Yano, I. (1985). Rhodococcus sputi sp. nov., nom. rev., and Rhodococcus aurantiacus sp. nov., nom. rev. Int $J$ Syst Bacteriol 35, 364-368.

Vuorio, R., Andersson, M. A., Rainey, F. A., Kroppenstedt, R. M., Kämpfer, P., Busse, H.-J., Viljanen, M. \& Salkinoja-Salonen, M. (1999). A new rapidly growing mycobacterial species, Mycobacterium murale sp. nov., isolated from the indoor walls of a children's day care centre. Int J Syst Bacteriol 49, 25-35.

Wayne, L. G., Brenner, D. J., Colwell, R. R. \& 9 other authors (1987). International Committee on Systematic Bacteriology. Report of the ad hoc committee on reconciliation of approaches to bacterial systematics. Int J Syst Bacteriol 37, 463-464.

Yamada, K. \& Komagata, K. (1972). Taxonomic studies on coryneform bacteria. IV. Morphological, cultural, biochemical, and physiological characteristics. J Gen Microbiol 18, 399-416. 